\title{
Physicochemical characteristics and sensory evaluation of bracken (Pteridium aquilinum) and Aster scaber dried by different methods
}

\author{
Gui-Hun Jiang ${ }^{1}$, Mi Og $\mathrm{Na}^{2}$, Jong-Bang Eun ${ }^{1 *}$ \\ ${ }^{1}$ Department of Food Science and Technology, Chonnam National University, Gwangju 61186, Korea \\ ${ }^{2}$ Department of Nursing, Hanlyo University, Gwang-yang 57764, Korea
}

\section{건조방법에 따른 고사리와 취나물의 이화학적 및 관능적 특성}

\author{
강귀훈 $^{1} \cdot$ 라미옥 ${ }^{2} \cdot$ 은종방 $^{1 *}$ \\ 1전남대학교 식품공학과 및 기능성식품연구센터, \\ 2한려대학교 간호학과
}

\begin{abstract}
The changes in physicochemical characteristics and sensory evaluation of bracken (Pteridium aquilinum) and Aster scaber dried by different methods sun-dried, hot-air-dried and freeze-dried were investigated. The freeze-dried Aster scaber showed the lowest moisture content than those of sun-dried and hot-air-dried. Freeze-dried bracken and Aster scaber showed higher rehydration rate than sun-dried and hot-air-dried. In the color values, the freeze-dried bracken and Aster scaber had the highest $\mathrm{L}^{*}$ value of 29.48 and 32.73, respectively, while freeze-dried Aster scaber showed the lowest a ${ }^{*}$ value of $\mathbf{- 6 . 7 8}$. Rehydrated bracken and Aster scaber after freeze-dried were the highest value in $\mathbf{L}^{*}$ and $\mathbf{b}^{*}$, while the lowest in a value. In sensory evaluation, freeze-dried bracken and Aster scaber showed the highest in color, appearance, flavor, texture and overall acceptability. There were no significant differences in texture between hot-air-dried bracken and freeze-dried bracken after rehydrating. However, freeze-dried bracken and Aster scaber were the highest in color, appearance, flavor and overall acceptability. In conclusion, freeze-dried bracken and Aster scaber showed the best rehydrated rate, color and sensory properties.
\end{abstract}

Key words : bracken, Aster scaber, physicochemical characteristics, sensory evaluation, drying methods

\section{서 론}

산채는 자연 그대로 산야에 자생하는 식물을 말하며 우 리나라의 산에서 자생하는 식용이나 약용의 식물은 대략 120 과 350 속으로 한국에서 자란 관속식물 중에서 약 $20 \%$ 를 차지하고 있으며, 이중에서 320 여종의 산채가 자생하고 있 다(1). 산채류는 비타민 또는 무기질이 풍부하며(2), 항 돌연 변이성 $(3,4)$, 암세포에 대한 세포독성 $(5,6)$, 간 기능개선 $(7,8)$, 항산화(9-11), 항비만(12-14), 항당뇨(15), 항균(16), 항

*Corresponding author. E-mail : jbeun@jnu.ac.kr

Phone : 82-62-530-2145, Fax : 82-62-530-2149

Received 12 April 2016; Revised 31 August 2016; Accepted 5 September 2016.

Copyright (c) The Korean Society of Food Preservation. All rights reserved.
염 $(17,18)$ 등 우수한 영양적인 효능들이 보고되었다. 산채 의 맛과 영양 그리고 생리활성은 급변하는 소비자의 요구를 충족할 수 있으므로 여러 가지 산채를 이용하여 기능성 탐색 또는 식품개발이 활발히 진행되고 있다.

산채 중 취나물(Aster scaber)과 고사리(Pteridium aquilinum) 는 우리나라에서 흔히 먹는 나물 중의 하나이며 일상적으로 현대인들이 쉽게 접할 수 있는 식재료이다. 그러나 맞벌이 부부와 독거 및 독신 생활자가 증가하고 있는 가운데, 취나 물 및 고사리와 같은 간편 조리 요리들을 원하고 있는 추세 인데 조리 방법이 번거로울 뿐만 아니라 조리 시간이 오래 걸린다. 따라서 이들의 조리 시간을 단축시키기 위해 천일 건조나 열풍건조를 사용하여 건조 참취나 고사리 제품을 생산하고 있다. 그러나 천일건조는 장기간의 건조 시간이 필요하며 수분함량의 조절이 용이하지 못할 뿐만 아니라 건조 중 미생물에 의해 오염될 가능성이 높고, 퇴색 또는 
영양성분의 파괴되어 품질이 저하된다(19). 또한 열풍건조 는 건조시간이 빠르고 경제적이며 신속하고 균일하게 건조 가 이루어지는 반면 수분손실에 의한 수축현상, 표면경화 현상, 건조 제품의 낮은 복원력, 퇴색, 조직감, 맛이나 영양 가 등이 저하되는 문제점이 대두되고 있다(20).

이에 반해 동결건조 식품은 바쁜 서민들의 식사 준비 기간을 줄이고 수분을 제거했기 때문에 가벼우며 실온에서 도 오래 동안 저장이 가능하다. 또한 국민 인식이 높아짐에 따라 단순한 영양식품이나 기호식품을 중시하는 식품에서 기능성, 건강성 및 간편성을 추구하는 제품의 개발이 주로 이루어지고 있어, 이에 따라 동결건조 제품 개발 시 고유의 풍미를 가지고 신선도 유지 및 다공성의 조직을 갖기 때문 에 물에 바로 재 수화되어 원래의 모양, 색깔, 조직감 및 맛 등을 갖도록 복원이 가능하다(21). 또한 제품의 예비동결 온도에 의해 빙결정의 크기와 수가 변하여 제품을 동결건조 시 조직과 다공성의 변화가 생기게 되며, 결과적으로 동결 건조제품의 복원속도 또는 품질에 큰 영향을 미치게 된다. 특히 간편성을 추구하는 동결건조 제품에 있어서 수화복원 율은 가장 중요한 품질 요소 중의 하나이다.

지금까지 건조식품에 관한 연구로는 건조 방법에 따른 곤드레 나물(22), 목이버섯(23), 매생이(24), 양송이버섯 (25), 마늘분말(26) 등 품질특성에 관한 연구들이 활발히 진행되고 있으나, 건조 방법에 따른 고사리와 취나물에 관 한 연구는 아직 미흡한 실정이다.

따라서 본 연구에서는 천일건조, 열풍건조 및 동결건조 를 이용한 수화복원 전후 건조된 고사리와 취나물의 이화학 적 및 관능적 특성을 통해 바쁜 현대인들의 조리시간을 줄이고 수화복원율이 빠르며 즉석섭취 가능한 건조방법을 알아보고자 하였다.

\section{재료 및 방법}

\section{실험재료}

본 실험에 사용한 고사리와 취나물은 전라남도 구례군 토지면의 농가에서 5 월에 수확한 고사리와 취나물을 각각 $10 \mathrm{~kg}$ 씩 아이스박스에 담은 후 전남대학교 식품공학과 식 품 가공 및 저장 실험실로 운반하여 냉장고 $4^{\circ} \mathrm{C}$ 에 저장하면 서 실험에 사용하였다.

\section{건조방법}

건조 고사리와 취나물의 제조를 위하여 우선 먼저 신선 한 고사리와 취나물을 흐르는 물에 3번 수세한 후 체와 키친타월을 이용하여 물기를 제거한 후 천일건조, 열풍건 조, 동결건조법을 사용하였으며, 천일건조는 $25^{\circ} \mathrm{C}$ 의 온도 와 $68 \%$ 의 습도로 48 시간 건조 하였고, 열풍건조는 열풍건 조기(Daesung Enertec, Sihueng, Korea)를 이용하여 $50^{\circ} \mathrm{C}$ 의
온도에서 14 시간 건조 했으며, 동결건조는 $-80 \pm 1^{\circ} \mathrm{C}$ 의 온도 로 동결건조기(SFDTIOH, Samwon, Pusan, Korea)를 이용 하여 건조하였다.

\section{수분함량}

건조 고사리와 취나물의 수분함량은 $\mathrm{AOAC}$ 방법(27)으 로 측정하였다. 항량이 측정된 수분수기에 고사리와 취나 물 시료를 $2 \mathrm{~g}$ 내외로 칭량한 후, 고사리와 취나물의 시료가 건조 항량에 도달할 때까지 $105^{\circ} \mathrm{C}$ 로 설정된 건조기 (FO-600M, Jeio Tech Co., Ltd., Kimpo, Korea)에서 2시간 한번 씩 측정을 하였다.

\section{수화복원력}

천일건조, 열풍건조 및 동결건조 된 고사리와 취나물 각 각 $150 \mathrm{~g}$ 을 stainless steel로 된 망에 넣어 $30^{\circ} \mathrm{C}$ 의 항온수조에 침지한 다음 2 시간 후 꺼내어 키친 타올로 시료의 표면수를 제거하고 whole 시료의 무게를 측정하여 각 건조 고사리와 취나물의 수화복원력을 측정하였다.

$$
\text { 원율 } \%)=\begin{gathered}
\text { 복원 후시료무게 }- \text { 복원 전 시료무게 } \\
\text { 복원 전 시료무게 } \times 100
\end{gathered}
$$

색 도

건조 된 고사리와 취나물, 그리고 건조 후 수화 복원 된 고사리와 취나물의 색도는 색차계(CM-3500D, Minolta, Tokyo, Japan)을 이용하여 명도(L", lightness), 적색도(a*, redness), 황색도( $\mathrm{b}^{*}$, yellowness)를 측정하였다.

관능검사

건조 된 고사리와 취나물, 그리고 건조 후 수화 복원 된 고사리와 취나물의 관능적 특성을 평가하기 위하여 실험에 대한 관심도와 검사원으로 적합성이 인정된 전남대학교 식품공학과 학부·대학원생 50 명을 대상으로 관능검사를 실시하였다. 평가원들에게 평가목적과 평가방법 등을 상세 히 설명한 후 7점 기호 척도법에 따라 실시하였다. 평가 항목은 외관, 색, 향, 조직감 및 전체적인 기호도의 항목으로 구성되었으며, 각 항목에 대하여 1점에서 7점까지 점수를 직접 기입하게 하였다 $(7$, 대단히 좋다; 6 , 보통으로 좋다; 5 , 약간 좋다, 4 , 좋지도 싫지도 않다, 3 , 약간 싫다, 2: 보통으 로 싫다; 1 , 대단히 싫다).

\section{통계처리}

본 실험은 동일한 조건의 시료를 각각 3 개씩 취하여 분석 하고자 하는 특성을 3 회씩 반복하여 분석하였으며 전체적 인 실험을 3회 반복 실시하여 SPSS program을 이용하여 분산분석을 실시하여 유의차가 인정되는 항목을 Duncan's multiple range test로 5\% 수준에서 각 처리구별로 유의성을 
검정하였다.

\section{결과 및 고찰}

\section{수분함량}

건조 방법을 달리하여 제조한 고사리와 취나물의 수분함 량은 Table 1 과 같다. 천일건조, 열풍건조 및 동결건조 방법 을 달리하여 제조한 건조 고사리 수분함량은 $10.47 \%$, $11.33 \%$ 및 $10.38 \%$ 를 나타냈고 서로 유의적인 차이를 보이 지 않았는데, 이는 건조 시간 및 온도에 기인한 것으로 보고 되어지고 있다(28). 건조 취나물의 경우에는 건조 방법을 달리한 수분함량이 6.17 11.36\% 범위를 나타내었고 동결 건조 된 취나물의 수분함량이 $6.17 \%$ 로 천일건조와 열풍건 조 된 취나물보다 가장 낮은 값을 나타내었다. Park 등(22) 의 연구에 의하면 건조 방법에 따른 곤드레 나물의 수분 함량을 측정한 결과, 열풍건조 곤드레 나물의 수분함량이 $7.5 \%$, 순환형감압 건조 곤드레 나물의 수분함량이 $7.8 \%$ 를 나타내어 본 연구결과에서의 건조 방법을 달리한 건조 취나 물의 수분함량(6.17 11.36\%)과 유사한 값을 나타내었다. 또한 Chung과 Choi(26)의 연구에서 건조방법을 달리하여 제조한 분말마늘이 열풍건조의 경우 $8 \%$, 동결건조의 경우 $3 \%$ 의 수분함량으로 보고되어, 동결 건조 마늘이 열풍건조 마늘보다 유의적으로 낮은 수분함량을 나타내어 본 연구결 과와 유사하였다.

Table 1. Changes of moisture contents of bracken and Aster scaber dried by different methods

\begin{tabular}{cccc}
\hline \multirow{2}{*}{ Sample } & \multicolumn{3}{c}{ Drying methods $^{1)}$} \\
\cline { 2 - 4 } & Sun-drying & Hot-air-drying & Freeze-drying \\
\hline Bracken & $10.47 \pm 0.85^{\mathrm{a} 2)}$ & $11.33 \pm 0.71^{\mathrm{a}}$ & $10.38 \pm 0.32^{\mathrm{a}}$ \\
\hline Aster scaber & $12.36 \pm 0.34^{\mathrm{c}}$ & $10.20 \pm 0.63^{\mathrm{b}}$ & $6.14 \pm 0.37^{\mathrm{a}}$ \\
\hline
\end{tabular}

${ }^{1)}$ Sun drying, dried at $25^{\circ} \mathrm{C}$ and $\mathrm{RH} 65 \%$ for $48 \mathrm{hr}$; Hot-air drying, dried in drying oven at $50^{\circ} \mathrm{C}$ for $14 \mathrm{hr}$; Freeze-drying, freeze-dried by vacuum-freeze dryer.

${ }^{2)}$ Means with different small letters $(\mathrm{a}-\mathrm{c})$ in the same row are significantly different at $\mathrm{p}<0.05$ by Duncan's multiple range test

\section{수화복원력}

건조식품의 복원력은 건조식품의 중요한 품질 특성 중의 하나이다. 특히 건조 과정 중 식품의 조직들이 손상되면 조직내의 용질들이 용출되므로 원상태로 복구 될 수 없다. 따라서 건조식품의 수화복원력은 건조 방법 및 온도에 의해 영향을 받게 된다. Fig 1과 Fig 2는 천일 건조, 열풍 건조, 동결 건조에 의하여 건조된 고사리와 취나물의 수화복원력 을 20 분 간격으로 총 120 분 측정하여 비교한 결과이다. 동 결건조 된 고사리와 취나물의 수화복원력은 $20,40,60$, 80,100 및 120 분에서 각각 $730,830,732,1,100,960$ 및 $970 \%$ 과 $480,680,700,620,630$ 및 $680 \%$ 를 나타냈으며
천일건조와 열풍건조 된 고사리와 취나물보다 우수한 수화 복원력을 갖는 것으로 확인 되었다. 20 분 간격으로 총 120 분 측정한 천일 건조와 열풍 건조에 의하여 건조된 고사리 와 취나물의 수화복원력은 서로 유의적인 차이를 보이지 않았다. 선행 연구에 의하면, 목이버섯(23), 양송이버섯(25) 및 라면(29)을 각각 열풍건조와 동결건조 한 후 수화복원력 을 측정한 결과, 모두 동결건조에서 우수한 복원력을 나타 내어 본 연구 결과와 일치하였다. 이는 동결건조 시 낮은 온도 및 높은 진공도에서 수분이 승화되는 속도가 빠르고 다공성이 많이 존재하는 것으로 사료된다(25). 따라서 고사 리와 취나물을 건조 시 동결건조가 천일건조와 열풍건조 보다 높은 수화복원력을 나타내었다. 즉 본 연구에서는 동 결건조 방법이 수화복원력이 우수한 것으로 나타내어 가장 적절할 것으로 판단된다.

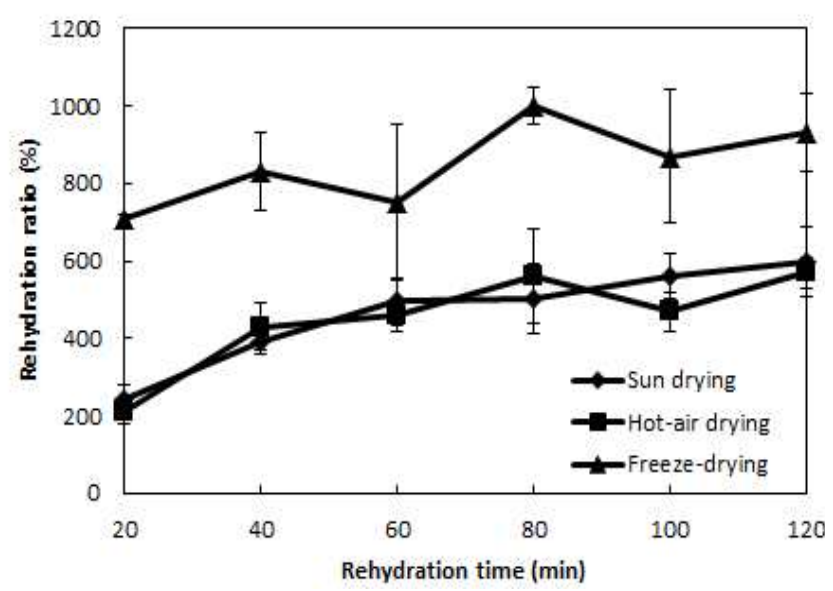

Fig. 1. Changes of rehydration rate of bracken dried by different methods.

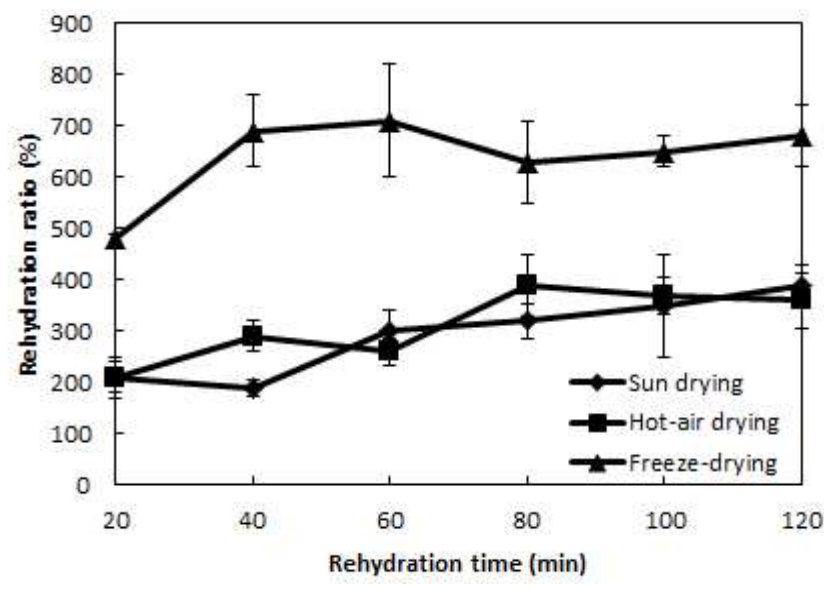

Fig. 2. Changes of rehydration rate of Aster scaber dried by different methods.

색 도

식품에 있어서 색은 맛, 향 및 영양성분과 함께 그 식품의 
가치를 나타내는 중요한 품질특성이다. 건조 방법을 달리 한 고사리와 취나물의 색도는 Table 2에 나타내었다. 명도 를 나타내는 $\mathrm{L}^{\star}$ 값은 9.83 29.48 범위를 나타내었고, 건조 취나물에서는 9.68 32.73 범위를 나타내었으며 동결건조 된 건조 고사리와 취나물이 29.48과 32.73으로써 가장 높은 값을 나타내었다. 적색 및 녹색을 나타내는 a ${ }^{*}$ 값에서 건조 고사리는 -0.85 1.70 범위를 나타냈고, 건조방법에 따라 유 의적인 차이를 보이지 않았으며, 건조 취나물에서는 -6.78 1.40 범위를 나타내었고, 동결건조 된 건조 취나물이 가장 낮은 값을 나타내었다. 이러한 결과는 상대적으로 동 결건조에 의해 제조된 시료가 천일건조와 열풍건조에 의해 제조된 시료에 비해 온도의 영향을 적게 받아 갈변현상이 거의 나타나지 않으므로 백색도는 가장 높고 반면에 적색도 는 낮게 나타난 것으로 사료된다. 건조조건이 오미자의 색 도에 미치는 영향에 관한 연구(30)에서 열풍 및 동결건조 된 오미자의 색도를 측정한 결과 $\mathrm{L}^{*}$ 값과 $\mathrm{a}$ "값이 열풍건조 시료에 비해 동결건조 된 시료에서 높았다고 보고하였다. Jeong 등(31)에 의하면 동결건조 및 열풍건조 원추리나물의 색깔 측정 결과를 살펴보면, 동결건조 원추리나물의 $\mathrm{L}^{*}$ 값 (69.08) $b^{*}$ (27.94)값은 모두 열풍건조 원추리나물보다 유의 적으로 높았으며, 반면에 $\mathrm{a}^{*}$ 값(-14.17)은 원추리나물보다 유의적으로 낮은 값을 나타내었다. 이는 본 연구결과의 색 깔 값과 유사한 것으로, 본 실험에서 동결건조 취나물 $\mathrm{a}^{*}$ 값이 -6.78 을 나타내어 가장 녹색에 가까워 나물의 고유의 색을 보유할 수 있을 것으로 판단된다. 황색도 $\mathrm{b}^{*}$ 값 경우 동결건조 된 건조 고사리와 취나물이 $\mathrm{L}^{*}$ 값과 유사하게 6.50 과 15.42 로써 가장 높은 값을 나타내었다. 따라서 동결건조 된 고사리와 취나물이 $\mathrm{L}^{*}$ 값과 $\mathrm{a}^{*}$ 값 및 $\mathrm{b}^{*}$ 값에 모두 영향을 미치는 것을 확인하였으며, 동결건조 방법이 고사리와 취 나물의 색 보유에 있어서 가장 적절한 건조방법으로 사료된다.

또한 건조방법에 따른 수화복원 된 고사리의 $\mathrm{L}^{*}$ 값은 7.83 23.95, a 값은 -1.82 -0.92 및 $\mathrm{b}^{*}$ 값은 -0.09 3.45 범위를 나타내었으며(Table 3), 동결건조 된 고사리가 천일건조와

Table 2. Changes of color values of bracken and Aster scaber dried by different methods

\begin{tabular}{ccccc}
\hline \multirow{2}{*}{ Samples } & \multirow{2}{*}{$\begin{array}{c}\text { Drying } \\
\text { methods }^{1)}\end{array}$} & \multicolumn{3}{c}{ Values } \\
\cline { 3 - 5 } & Sun-drying & $12.81 \pm 1.57^{\mathrm{a} 2)}$ & $1.33 \pm 0.78^{\mathrm{a}}$ & $1.91 \pm 1.10^{\mathrm{a}}$ \\
\multirow{3}{*}{ Bracken } & Hot-air-drying & $9.83 \pm 1.01^{\mathrm{a}}$ & $-0.85 \pm 0.44^{\mathrm{a}}$ & $-0.20 \pm 1.06^{\mathrm{a}}$ \\
& Freeze-drying & $29.48 \pm 4.36^{\mathrm{b}}$ & $1.70 \pm 3.47^{\mathrm{a}}$ & $6.50 \pm 2.47^{\mathrm{b}}$ \\
\hline \multirow{4}{*}{ Aster scaber } & Sun-drying & $9.68 \pm 4.35^{\mathrm{a}}$ & $0.14 \pm 1.19^{\mathrm{c}}$ & $3.45 \pm 1.08^{\mathrm{a}}$ \\
& Hot-air-drying & $14.00 \pm 2.12^{\mathrm{a}}$ & $-1.66 \pm 0.26^{\mathrm{b}}$ & $5.34 \pm 1.09^{\mathrm{a}}$ \\
& Freeze-drying & $32.73 \pm 1.55^{\mathrm{b}}$ & $-6.78 \pm 1.14^{\mathrm{a}}$ & $15.42 \pm 1.21^{\mathrm{b}}$ \\
\hline
\end{tabular}

${ }^{1)}$ Sun drying, dried at $25^{\circ} \mathrm{C}$ and $\mathrm{RH} 65 \%$ for $48 \mathrm{hr}$; Hot-air drying, dried in drying oven at $50^{\circ} \mathrm{C}$ for $14 \mathrm{hr}$; Freeze-drying, freeze-dried by vacuum freeze dryer.

${ }^{2)}$ Means with different small letters $(\mathrm{a}-\mathrm{c})$ in the same column are significantly different at $p<0.05$ by Duncan's multiple range test.
열풍건조 된 고사리보다 $\mathrm{L}^{*}, \mathrm{a}^{*}$ 및 $\mathrm{b}^{*}$ 값이 모두 유의적으로 높은 값을 나타내었다. 동결 건조 취나물은 $\mathrm{L}^{*}$ 값과 $\mathrm{b}^{*}$ 값이 30.73 과 13.72 로써 다른 건조방법 보다 유의적으로 높은 값을 보였으며, $\mathrm{a}^{*}$ 값에서는 -8.87 로써 가장 낮은 값을 나타 내어 나물의 색상을 보유하였다. 따라서 수화복원 된 동결 건조 취나물의 경우 a*값이 낮아 녹색을 띄어 바람직한 결과 를 나타내었다.

Table 3. Changes of color value of rehydrated bracken and Aster scaber dried by different methods

\begin{tabular}{ccccc}
\hline \multirow{2}{*}{ Samples $^{1)}$} & Drying $^{2)}$ & \multicolumn{3}{c}{ Value } \\
\cline { 3 - 5 } methods $^{*}$ & $\mathrm{~L}^{*}$ & $\mathrm{a}^{*}$ & $\mathrm{~b}^{*}$ \\
\hline \multirow{3}{*}{ Bracken } & Sun-drying & $11.61 \pm 1.04^{\mathrm{b3})}$ & $-0.92 \pm 0.28^{\mathrm{b}}$ & $-0.09 \pm 1.10^{\mathrm{b}}$ \\
& Hot-air-drying & $7.83 \pm 1.01^{\mathrm{a}}$ & $-2.85 \pm 0.44^{\mathrm{a}}$ & $-2.20 \pm 1.06^{\mathrm{a}}$ \\
& Freeze-drying & $23.95 \pm 1.55^{\mathrm{c}}$ & $-1.30 \pm 1.65^{\mathrm{b}}$ & $3.45 \pm 1.16^{\mathrm{c}}$ \\
\hline \multirow{3}{*}{ Aster scaber } & Sun-drying & $8.88 \pm 2.43^{\mathrm{a}}$ & $-1.86 \pm 1.19^{\mathrm{c}}$ & $1.45 \pm 1.08^{\mathrm{a}}$ \\
& Hot-air-drying & $12.00 \pm 2.12^{\mathrm{b}}$ & $-3.66 \pm 0.26^{\mathrm{b}}$ & $3.34 \pm 1.09^{\mathrm{b}}$ \\
& Freeze-drying & $30.73 \pm 1.55^{\mathrm{c}}$ & $-8.78 \pm 1.14^{\mathrm{a}}$ & $13.42 \pm 1.21^{\mathrm{c}}$ \\
\hline
\end{tabular}

${ }^{1)}$ Samples were rehydrated at $30^{\circ} \mathrm{C}$ for 2 hours after dried by different methods. ${ }^{2)}$ Sun drying, dried at $25^{\circ} \mathrm{C}$ and $\mathrm{RH} 65 \%$ for $48 \mathrm{hr}$; Hot-air drying, dried at $50^{\circ} \mathrm{C}$ in for $14 \mathrm{hr}$; Freeze-drying, freeze-dried by vacuum freeze dryer.

${ }^{3}$ Means with different small letters $(\mathrm{a}-\mathrm{c})$ in the same column are significantly different at $\mathrm{p}<0.05$ by Duncan's multiple range test.

관능검사

천일건조, 열풍건조 및 동결건조 된 고사리와 취나물의 관능적 특성을 7점 척도법으로 조사하였으며 결과를 Table 4 에 나타내었다. 동결건조 된 고사리와 취나물에서 색은 5.70 과 5.70 , 향은 5.30 과 5.40 , 외관은 5.30 과 5.50 , 조직감은 4.50 과 4.80 및 전체적인 기호도에서는 5.70 과 5.80 으로써 모두 천일건조와 열풍건조 된 고사리와 취나물보다 높은 값을 나타내었다. 이는 천일 건조, 열풍 건조는 건조 후 외형적 변화 및 갈변으로 인해 색깔이 바람직하지 않는 것으로 관능검사 결과에서 낮은 값을 나타내었다고 생각되 며 다른 건조 방법보다 동결 건조를 실시하여 제조한 것이 소비자들에게 좋은 인식을 주어 상품성이 향상되어 농가의 소득 증대에도 기여할 수 있을 것으로 판단된다.

건조 방법에 따라 수화복원 된 고사리와 취나물의 관능 검사를 나타낸 결과, 수화복원 된 동결건조 고사리가 조직 감에서는 4.80 으로써 다른 건조방법에 의해 수화복원 된 고사리와 유의적인 차이를 보이지 않았으나(Table 5), 조직 감을 제외한 색, 향, 외관, 전체적인 기호도에서는 모두 유의 적으로 높은 값을 나타내었다. 건조 방법에 따라 수화 복원 된 취나물의 관능검사 결과 색, 향, 외관, 조직감, 전체적인 기호도에서 모두 동결건조에 의하여 건조 된 취나물에서 천일건조와 열풍건조 된 취나물 보다 유의적으로 높은 값을 나타내었다. 
Table 4. Sensory evaluation of bracken and Aster scaber dried by different drying methods

\begin{tabular}{|c|c|c|c|c|}
\hline \multirow{2}{*}{ Samples } & & \multicolumn{3}{|c|}{ Drying methods ${ }^{1)}$} \\
\hline & & Sun-drying & Hot-air-drying & Freeze-drying \\
\hline \multirow{5}{*}{ Bracken } & Color & $3.40 \pm 0.52^{\mathrm{a} 2)}$ & $3.40 \pm 0.52^{\mathrm{a}}$ & $5.20 \pm 0.79^{b}$ \\
\hline & Flavor & $3.40 \pm 0.52^{\mathrm{a}}$ & $3.40 \pm 0.52^{\mathrm{a}}$ & $5.30 \pm 0.67^{\mathrm{b}}$ \\
\hline & Appearance & $2.90 \pm 0.74^{\mathrm{a}}$ & $2.90 \pm 0.74^{\mathrm{a}}$ & $5.30 \pm 0.67^{b}$ \\
\hline & Texture & $1.70 \pm 0.48^{\mathrm{a}}$ & $1.70 \pm 0.48^{\mathrm{a}}$ & $4.50 \pm 0.53^{b}$ \\
\hline & $\begin{array}{c}\text { Overall } \\
\text { acceptability }\end{array}$ & $2.50 \pm 0.53^{\mathrm{a}}$ & $2.50 \pm 0.53^{\mathrm{a}}$ & $5.70 \pm 0.67^{b}$ \\
\hline \multirow{5}{*}{ Aster scaber } & Color & $2.60 \pm 0.52^{\mathrm{a}}$ & $2.70 \pm 0.48^{\mathrm{a}}$ & $5.70 \pm 0.82^{b}$ \\
\hline & Flavor & $2.50 \pm 0.53^{\mathrm{a}}$ & $2.80 \pm 0.42^{\mathrm{a}}$ & $4.80 \pm 0.63^{b}$ \\
\hline & Appearance & $2.60 \pm 0.52^{\mathrm{a}}$ & $2.70 \pm 0.48^{\mathrm{a}}$ & $5.60 \pm 0.52^{b}$ \\
\hline & Texture & $2.70 \pm 0.48^{\mathrm{a}}$ & $2.90 \pm 0.57^{\mathrm{a}}$ & $5.40 \pm 0.52^{\mathrm{b}}$ \\
\hline & $\begin{array}{c}\text { Overall } \\
\text { acceptability }\end{array}$ & $2.90 \pm 0.74^{\mathrm{a}}$ & $2.80 \pm 0.42^{\mathrm{a}}$ & $6.20 \pm 0.79^{b}$ \\
\hline
\end{tabular}

${ }^{1)}$ Sun drying, dried at $25^{\circ} \mathrm{C}$ and $\mathrm{RH} 65 \%$ for $48 \mathrm{hr}$; Hot-air drying, dried in drying oven at $50^{\circ} \mathrm{C}$ for $14 \mathrm{hr}$; Freeze-drying, freeze-dried by vacuum freeze dryer.

${ }^{2)}$ Means with different small letters $(\mathrm{a}-\mathrm{b})$ in the same row are significantly different at $\mathrm{p}<0.05$ by Duncan's multiple range test.

Table 5. Sensory evaluation of rehydrated bracken and Aster scaber dried by different methods

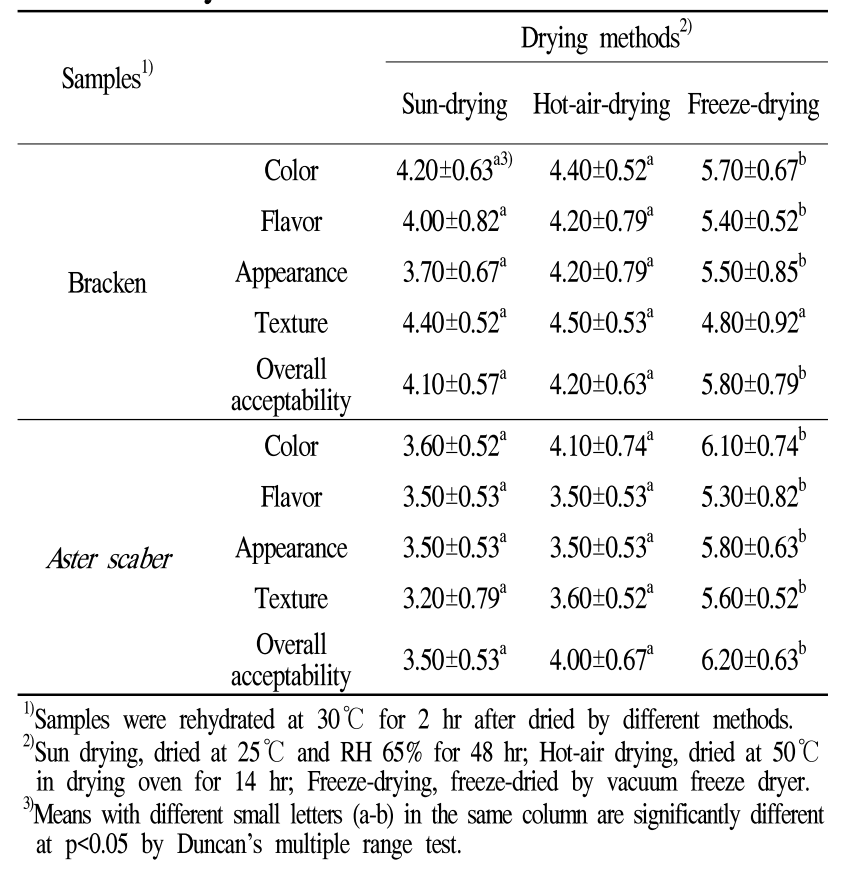

\section{요 약}

본 연구에서는 건조방법을 달리하여 수화복원 전후 건조 된 고사리와 취나물의 이화학적 및 관능적 특성을 조사하였 다. 수분함량에서 동결건조 된 취나물이 천일건조와 열풍 건조 된 취나물보다 낮은 값을 나타내었으며, 수화복원력
은 동결건조 된 고사리와 취나물이 천일건조와 열풍건조 된 고사리와 취나물보다 모두 높은 복원력을 나타내었다. 색도 $\mathrm{L}^{*}$ 값에서는 동결건조 된 고사리와 취나물이 천일건조 와 열풍건조 된 취나물보다 유의적으로 높은 값을 나타내었 으며, 반면에 동결건조 된 취나물의 경우 가장 낮은 $\mathrm{a}^{\star}$ 값을 나타내었다. $b^{*}$ 값에서는 동결건조 된 고사리와 취나물이 모두 높은 값을 나타내었다. 수화복원 된 고사리와 취나물 의 색도에서는 동결건조 된 고사리의 $\mathrm{L}^{*}, \mathrm{a}^{*}$ 및 $\mathrm{b}^{*}$ 값이 높은 값을 나타내었고, 취나물의 경우 $\mathrm{L}^{*}$ 과 $\mathrm{b}^{*}$ 값이 높은 값을 나타내었으며, $\mathrm{a}^{*}$ 값은 가장 낮게 나타내었다. 관능평가에서 는 수화복원 전 후 동결 건조된 고사리와 취나물의 색, 향, 외관 및 전체적인 기호도에서 천일건조와 열풍 건조된 고사 리와 취나물보다 모두 유의적으로 높은 값을 나타내었으 나, 결론적으로 동결건조 고사리와 취나물이 열풍건조와 천일 건조된 고사리와 취나물 보다 수화복원력이 가장 빠르 고, 나물의 고유 색상을 유지하며 또한 관능적으로도 아주 우수한 것으로 보아 만약 상품화한다면 비록 가격은 비싸지 만 바쁜 현대인들을 대상으로 빨리 섭취 할 수 있는 간편식 제품으로 이용 가능할 것으로 사료된다.

\section{감사의 글}

본 연구는 2008년 5월부터 2009년 5월까지 농림수산식 품부 농림기술 관리센터의 지원 사업비로 이루어진 결과이 며, 이에 감사드립니다.

\section{References}

1. Cho EJ (2000) A survey on the usage of wild grasses. Korean J Dietary Culture, 15, 59-68

2. Kim YD, Yang WM (1986) Studies on the components of wild vegetables in Korea. J Korean Soc Food Nutr, $15,10-16$

3. Ham SS, Lee SY, Choi M, Hwangbo HJ (1998) Antimutagenicity and cytotoxicity effects of Woorimil wheat flour extracts added with wild herb and seaweed powder. J Korean Soc Food Sci Nutr, 27, 1177-1182

4. Hwangbo HS, Ham SS (1999) Antimutagenic and cytotoxic effects of Aster scaber root ethanol extract. Korean J Food Sci Technol, 31, 1065-1070

5. Bae JH, Yu SO, Kim YM, Chon SU, Kim BW, Heo BG (2009) Physiological activity of methanol extracts from Ligularia fischeri and their hyperplasia inhibition activity of cancer cell. J Bio-Environment Cont, 18, 67-73 6. Yu MH, Im HG, Lee HJ, Ji YJ, Lee IS (2006) 
Components and their antioxidative activities of methanol extracts from sarcocarp and seed of Zizyphus jujuba var. inermis Rehder. Korean J Food Sci Technol, 38, 128-134

7. Kim HS, Kim GJ, Kim HS (1998) Effect of the feeding Platycodon grandiflorum on lipid components of liver and liver function in hypercholesterolemic rats. Korean J Food Nutr, 11, 312-318

8. Whang TE, Lim HO, Lee JW (1999) Effect of fermented (Oenanthe stolonifera DC) extract of the activity on enzymes related to liver function of alcohol-administered rats and mice. Korean J Medicinal Crop Sci, 7, 107-114

9. Noh KS, Yang MO, Cho EJ (2002) Nitrite scavenging effect of Umbelliferaeceae. Korean J Soc Food Cookery Sci, 18, 8-12

10. Heo SJ, Yang MO, Cho EJ (2001) Analysis of Umbelliferaeceae wild plants and antioxidative activity of pork meat products added with wild plants. Korean J Soc Food Cookery Sci, 17, 456-463

11. Lee SO, Lee HJ, Yu MH, Im HG, Lee IS (2005) Total polyphenol contents and antioxidant activities of methanol extracts from vegetable produced in Ullung island. Korean J Food Sci Technol, 37, 233-240

12. Kim EY, Jung EY, Lim HS, Heo YR (2007) The effects of the Sasa borealis leaves extract on plasma adiponectin, resistin, C-reactive protein and homocysteine levels in high fat diet-induced obese C57/BL6J mice. Korean J Nutr, 40, 303-311

13. Lim SS, Lee JH (1997) A study on the chemical composition and hypocholesterolamic effect of Aster scaber and Lxeris dentata. J Korean Soc Food Sci Nutr, 26, 123-129

14. Lee HJ, Chung MJ, Kim DJ, Choe M (2009) Effects of Oenanthe javanica, Coicis lachryma-jobi L. var., and Plantaginis asiatica L. water extracts on activities of key enzymes on lipid metabolism. J Korean Soc Food Sci Nutr, 38, 1516-1521

15. Choi JW, Kim WB, Nam JH, Park HJ (2007) Anti-diabetic effect of the methanolic extract of Ligularia stenocephala leaves in the streptozotocin-induced rat. Korean J Plant Res, 20, 362-366

16. Moon YG, Choi KS, Lee KJ, Kim KY, Heo MS (2006) Screening of antioxidative and antibacterial activity from hot water extracts of indigenous plants, Jeju-island. Korean J Biotechnol Bioeng, 21, 164-169

17. Koh YJ, Park YK, Kim YS, Cha DS, Choi HD (2009) Preparation of hot water extracts of dandelion leaves to increase anti-inflammatory activity. J Korean Soc Food Sci Nutr, 38, 391-395

18. Park JC, You YB, Lee JH, Kim NJ (1994) Anti- inflammatory and analgesic effects of the components from some edible plants. J Korean Soc Food Nutr, 23, 671-674

19. Kim KH, Kang JK, Park HW (2000) Quality maintenance of minimally processed Chinese cabbage for kimchi preparation. J Korean Soc Food Sci Nutr, 29, 218-223

20. Holdsworth SD (1971) Dehydration of food products. J Food Technol, 6, 331-336

21. Kim SS, Kim IH, Kim KS, Yang JW, Park JH (2008) Current status and prospects of the space food development. Food Science and Industry, 4, 63-82

22. Park SJ, Lee DW, Park SH, Rha YA (2016) Quality characteristics of Cirsium setidens Nakai by different drying method. Cul Sci Hos Res, 22, 104-114

23. Choi SR, Yu YJ, Ahn MS, Song EJ, Seo SY, Choi MK, Han HA, Song YJ, Kim HJ, So SY, Lee GK, Kim CK (2014) Quality characteristics by various drying methods in ear mushroom (Auricularia auricula-judae Quel.). Korean J Medicinal Crop Sci, 22, 497-503

24. Son SM, Kwon HO, Lee JH (2011) Physicochemical composition of Capsosiphon fulvescens according to drying methods. J Korean Soc Food Sci Nutr, 40, $1582-1588$

25. Ha YS, Park JW, Lee JH (2001) Physical characteristics of mushroom (Agaricus bisporus) as influenced by different drying methods. Korean J Food Sci Technol, 33, 245-251

26. Chung SK, Choi JU (1990) The effects of drying methods on the quality of the garlic powder. Korean J Food Sci Technol, 22, 44-49

27. AOAC (1990) Official Method of Analysis of AOAC International 14th ed, Association of official analytical chemists, Arlington, VA, USA

28. Joo HK, Kim SS, Sa TM (1995) Effect of drying condition on the colors and flavors change of fresh pepper. $J$ Oriental Bot Res, 8, 115-125

29. Song BS, Park JG, Park JN, Han IJ, Choi JI, Kim JH, Byun MW, Kang SW, Choi GH, Lee JH (2009) High-dose processing and application to Korean space foods. Radiat Phys Chem, 78, 671-674

30. Kim YJ, Lee YG, Choi YW, Kim YC (2008) Effects of drying conditions on the profile of volatile terpenoid and colour of schizandra fruit (Schizandra Chinensis fructus). J Life Sci, 18, 1066-1071

31. Jeong JS, Kim YJ, Choi BR, Park NJ, Son BG, Kwak YS, Kim JC, Cho KH, Kim IH, Kim SH (2013) Physicochemical changes in Hemerocallis coreana Nakai after blanching, drying, and fermentation. J Korean Soc Food Sci Nutr, 42, 1638-1648 